\title{
Research on Tourism Development of Opium War Museum Based on Network Text Analysis
}

Dengyu Jiang ${ }^{1 *}$, Yunxin $\mathrm{Fu}^{2}$

${ }^{1}$ Jinan University, Guangzhou, China

${ }^{2}$ Department of Tourism Management, School of Management, Jinan University, Guangzhou, China

Museum tourism is the main content of urban tourism and cultural tourism, and it is a form of tourism that has emerged in recent years. However, the museum itself is a non-profit charity, and most of its funding sources are government support. The development of tourism in museums is based on the traditional social functions of museums to protect cultural relics and display culture, to build tourism facilities and to carry out tourism projects to realize the economic functions of the museum. This paper takes the Opium War Museum in Humen Town, Dongguan, Guangdong Province as a case study. Through the online text analysis of Ctrip.com visitors' comments, combined with field visits, it conducts tourism development evaluation. Finally, from the perspective of scenic spot development, industry management and investment mechanism, and government support policy. Advising on the economic benefits of tourism development at the Opium War Museum.

Keywords: Museum, tourism development, economic benefit, network text analysis.

Copyright @ 2020: This is an open-access article distributed under the terms of the Creative Commons Attribution license which permits unrestricted use, distribution, and reproduction in any medium for non-commercial use (NonCommercial, or CC-BY-NC) provided the original author and source are credited.

\section{INTRODUCTION}

In the traditional sense, the basic functions of museums are mainly social functions, properly protecting cultural relics, displaying national culture, and promoting academic exchanges and social progress [1]. Due to the development of museum tourism, the economic function of the museum is also highlighted. Museum tourism is based on the museum's collection of cultural relics, showing tourists the national culture or local characteristics of culture, providing a leisurely new form of tourism, belonging to cultural tourism and urban tourism [2]. To carry out museum tourism is not to abandon its basic functions, but to enhance the activation and utilization value of cultural relics, so as to better disseminate culture, promote the improvement of people's quality, improve the social environment of people's lives, and realize the all-round development of people and the overall progress of society. Create good conditions and achieve their social and economic functions.

As a non-profit public welfare institution, the museum is contrary to the nature of the tourism industry's pursuit of profit. After the implementation of the museum's free and open policy, the museum relied mainly on government support and social donations, and its economic benefits through tourism were very small.

\section{Study background and objectives}

The Opium War Museum is located in Humen Town, Dongguan, Guangdong Province. It consists of four parts: "Lin Zexu's Old Tobacco Site (Main Building)", "Sea Battle Museum", "Shajia Fortress Site" and "Weiyuan Fortress Site". The Lin Zexu sales pool and the Humen Fort site are the national key cultural relic's protection units. It is a monumental and ruined historical museum with a total area of 800,000 square meters. It shows the history and culture of the Opium War period and is an important patriotic education base in China.

There are 49 unique museums in Dongguan, Guangdong Province, among which 8 are museums, 10 towns (street) museums, 31 private museums, a comprehensive Dongguan Museum, and the Dongguan Science and Technology Museum of Natural Science and Technology. The Dongguan Opera Museum of the historical resources category, the Dongqiao Art Museum of the folk collections, etc. can be described as the "city of museums"[3]. Therefore, if Dongguan starts from the museum, it will have great advantages in developing cultural tourism and urban tourism. How does the Opium War Museum stand out from the crowd 
and create a travel brand with a lot of room for development.

This paper evaluates the current situation of tourism development of the Opium War Museum through online commentary analysis and field trips, and proposes corresponding suggestions.

\section{METHODS}

With the popularity of web applications, people are increasingly interested in publishing or accessing information on the web. Visitors who voluntarily leave the online community in a private environment after the visit have a higher degree of freedom of evaluation and can more realistically reflect the visitors' perception of the scenic spot [4]. This article collected 196 valid comments from Ctrip.com on the Opium War Museum from January 1, 2017 to January 28, 2017. After all the comments were simply sorted out, the ROST CM6 software was used to process the comment texts. The meaningless words in the text after the word segmentation are deleted, and the synonyms are summarized. For example, the words "not interesting", "insufficient interest" and "no interest" are unified as "lack of interest", "worth to go", "must see The words "see" and "recommended visit" are unified as "recommendation"; finally, the word frequency statistics are performed on the collated text using ROST CM6. The statistical results are divided into three categories: "positive evaluation", "negative evaluation", "neutral words" for tourists' perception of museum image or suggestions for other tourists, and are arranged according to the frequency of words from high to low. The results are shown in Table 1:

Table-1: Ctrip.com visitors to the Opium War Museum commentary frequency table

\begin{tabular}{|c|c|c|c|c|c|}
\hline \multicolumn{6}{|c|}{ Positive comments } \\
\hline Sorting & word & Frequency & Sorting & word & Frequency \\
\hline 1 & recommended & 57 & 10 & Would like to revisit & 2 \\
\hline 2 & shock & 23 & 11 & Interpretation of the vivid & 2 \\
\hline 3 & free & 21 & 12 & Good location & 2 \\
\hline 4 & Beautiful scenery & 21 & 13 & leisure & 1 \\
\hline 5 & Collection is rich & 10 & 14 & A lot of snacks & 1 \\
\hline 6 & Landmark attraction & 7 & 15 & Modern facilities & 1 \\
\hline 7 & Not bad & 6 & 16 & Wide area & 1 \\
\hline 8 & The transportation is convenient & 3 & 17 & The air is clear & 1 \\
\hline 9 & solemn & 2 & 18 & The wind is cool & 1 \\
\hline \multicolumn{6}{|c|}{ Negative evaluation } \\
\hline Sorting & word & frequency & Sorting & word & frequency \\
\hline 1 & boring & 7 & 8 & Bad surroundings & 1 \\
\hline 2 & Small area & 5 & 9 & Narrow road & 1 \\
\hline 3 & Disorder of surrounding security & 5 & 10 & Traffic jam & 1 \\
\hline 4 & The lack of interpretation & 3 & 11 & Traffic inconvenience & 1 \\
\hline 5 & Geographically remote & 3 & 12 & Lack of rest area & 1 \\
\hline 6 & Parking inconvenience & 3 & 13 & High souvenir prices & 1 \\
\hline 7 & mismanagement & 2 & 14 & Poor quality of souvenirs & 1 \\
\hline \multicolumn{6}{|c|}{ Neutral evaluation } \\
\hline Sorting & word & frequency & Sorting & word & frequency \\
\hline 1 & Historical memorial & 83 & 5 & Drugs harm & 14 \\
\hline 2 & Patriotic education & 65 & 6 & Humen bridge & 9 \\
\hline 3 & With the children & 18 & 7 & seaview & 5 \\
\hline 4 & battery & 17 & 8 & Over the weekend & 3 \\
\hline
\end{tabular}

\section{RESULTS}

According to the statistical results, among the 40 words sorted out, tourists have the largest proportion of "neutral words" in the image of the Opium War Museum or the recommendations of other tourists. In the eyes of tourists, the Opium War Museum is It is a national patriotic education base that commemorates the history and warns of the dangers of opium drugs. It is suitable for guiding children to visit and study in their leisure time. Secondly, the larger proportion is positive evaluation of the words, indicating that tourists are still quite satisfied with the Opium War Museum. They believe that the Opium War Museum has a wide area and beautiful scenery. With modern facilities, the rich collections are vivid and shocking. Spectacular, and as an iconic attraction in Humen Town and even Dongguan, most tourists are willing to revisit or recommend to others under the cost-effective free policy. However, in the statistical results, we also saw some negative evaluation words. The author combined field trips to the Opium War Museum from five aspects: infrastructure, attraction facilities and tourist areas, tourism service facilities, human resources development, and tourism market development. Analysis of the current status of tourism development. 


\section{INFRASTRUCTURE}

There are many residential buildings in the vicinity of the opium war museum (the main site of the museum) where Lin zexu is located, and the roads are narrow and damaged. Some large vehicles are difficult to enter, and traffic jams are easy in busy seasons. Secondly, there are many vendors at the gate of the scenic spot, so the hygiene and safety of food sold and the quality of souvenirs cannot be guaranteed. The lack of management of non-standard behavior of community participation in tourism will leave tourists with the impression of disorder and bad social security. Finally, in today's developed network communication, people communicate and share through mobile phones, and the museum headquarters also has the explanation of network scanning code. However, the network communication signal of the museum headquarters is weak, which is difficult to meet the needs of tourists.

The maritime war museum is far away from the downtown area, and the surrounding environment is relatively stable, which provides stable conditions for the protection of the old fort site, and avoids the damage of community life to the surrounding environment of the scenic spot. However, the geographical location is slightly remote, with less access to public transport, which is not very convenient for non-self-driving individual travelers.

All three locations are accessible only by firstline buses. In addition, the museum headquarters and shajiao fortress are scattered in the northeast $26.2 \mathrm{~km}$ and the southeast $30.4 \mathrm{~km}$ of the naval war museum, and there is no direct bus, making it difficult for tourists to move between the three sites.

\section{Attractors and environments \\ Brand image of scenic spot}

Lin zexu's famous anti-drug campaign awakened the patriotic consciousness of the Chinese people. The opium war museum manages two national key cultural relics are the site of Lin zexu's humen opium war and the site of the ancient opium war battlefield. The four attractions of the opium war museum are of great patriotic education and historical significance, and are important bases of patriotic education and anti-drug education in China.

\section{Collection contents}

These two museums have rich collections, which use a lot of methods such as scene restoration and video screening, and the whole display is lively and interesting. However, both museums have been pointed out by tourists that the interest is not strong; the main reason is that the two museums lack of interactive activities, the display of cultural relics can only meet the tourists' demand for sightseeing.

\section{Scenic environment}

The naval war museum is located at the Pearl River port, close to Humen Bridge, and the museum covers a large area with trees and beautiful scenery. The south west gate of the naval war museum can be walked to weiyuan fortress within 6 minutes. The two scenic spots are adjacent to each other, which makes the tour contents of tourists richer and more convenient.

Although the museum headquarters is located in the downtown area and occupies a small area, it is still green and quiet, in line with the serious theme of long history, drug control and patriotic education.

\section{Tourist service facilities}

As a public welfare social institution, museums need to meet tourists' six basic needs of food, accommodation, travel, travel, shopping and entertainment if they want to develop the for-profit tourism industry.

The pavilion is located in a busy residential area, and there are many shops around, so the catering needs are easy to be solved. However, there are also many food vendors near the scenic spot, so the sanitation and safety are not up to standard. There are many hotels within 2 kilometers of the museum, including fast 8 , jinjiang star, seven days and other economic chain hotel brands. There are also relatively high-end Rhine hotels, which can meet the accommodation needs of different tourists. There are souvenir shops in the scenic spot, but some tourists report that the price is a little expensive; In addition, 4.4 kilometers away from the museum are large shopping malls such as wanda plaza, which can meet most of the entertainment needs of tourists.

The maritime war museum is located in a remote area, and there are few food shops around. However, there is a row of snack stalls at the southeast gate of the scenic spot, and a retail store at the southwest gate, which can barely meet the needs of tourists. Around $4 \mathrm{~km}$ away from the hotel, accommodation is not very convenient; Shopping and entertainment venues are also scarce, and visitors need to return to the city.

Four scenic spots are located in three places with a certain distance, the lack of scenic spots between the shuttle buses; the naval war museum covers a large area, and tourists report that it is far from the scenic spot and the distance to the weiyuan fortress, without ferries. In terms of sightseeing, there is a lack of leisure facilities in the scenic spots and few rest areas in the museum. For the middle-aged, elderly and children tourists, the one-breath tour will be a little tiresome. 


\section{Human resources development}

Tourism as a service industry, the development of human resources is the fundamental driving force for its development [5]. The opium war museum has its own volunteer service team, most of which are engaged in activities to assist or audience evacuation, and there are few volunteers to explain and guide visitors. Although the museum has set up a network scanning code cultural relic's explanation, but this form may make visitors feel cold, lack of interaction between people, explanation is not deep enough, not personalized enough.

\section{Tourism market development}

In April 2008, "notice on free opening of national museums and memorial halls" was officially released, and the work of free opening of national museums to the public was officially launched. The free admission policy of museums has lowered its economic threshold, enabling more and more tourists from different economic conditions to choose museums and expand the market. But at the same time, the museum's free policy also reduces the museum's economic income.

The museum of opium war is more likely to attract history lovers or family travelers due to its image of historical memorial, anti-drug education and patriotic education base. However, in the current trend of museum tourism, as one of the important contents of cultural tourism and urban tourism, the opium war museum has a single tourism product and lacks diversified market development, which is difficult to meet tourists' leisure needs.

\section{DISCUSSION}

Through the above analysis, the following Suggestions are proposed

\section{Construction of scenic spots Souvenir development}

When visitors arrive at a tourist site, they usually want to take pictures or buy souvenirs for future memories [6]. Most museums forbid visitors from taking photos to avoid the damage caused by flashlights. Therefore, the opium war museum can combine the theme of humen and the opium war to carry out cultural creative design and sell souvenirs, such as postcards and small decorations related to the featured exhibits, so as to minimize the intermediate links and ensure the quality of the goods at a reasonable price. In addition, diversified products should be designed according to different price levels to meet the shopping needs of tourists at different consumption levels. You can also update the commemorative products according to the current theme of the mobile exhibition. The sale of memorabilia can add some economic value to the museum.

\section{Open a special tourist line}

The transportation service between scenic spots and scenic spots and between scenic spots can also be regarded as one of the economic income projects of scenic spots. The opium war museum's four scenic spots are scattered in three places, far apart and without direct buses. Tourist traffic in scenic spots can not only realize the turnover of tourists among scenic spots, but also realize the diversion of tourists, so as to balance the supply and demand between tourists and scenic spots. Therefore, the opium war museum should open a special tour bus between the naval war museum, the opium war museum headquarters and sha jiao fortress. Because the naval war museum covers a relatively large area, the scenic spot can also be opened to the tourist car service.

\section{Increase the publicity of the activity}

The propaganda department of the opium war museum has created an experiential brand of "discovery workshop" and organized many activities with distinctive features; including 88 in 2017.The opium war museum needs to combine the basic exhibition of the exhibition hall with the theme of different mobile exhibitions to carry out more educational activities targeted at tourists of all ages. At the same time, strengthen the promotion of activities on the official website, online tourism community, online life group purchase and other platforms. Only in this way can the market coverage of different groups of the museum be expanded and the influence of the opium war museum be enhanced.

\section{Set up leisure places in the museum}

A museum should not only be a place for the preservation and display of cultural relics in the traditional sense, but also a social space for learning and communication. The opium war museum can introduce catering, movie theaters, bookstores, banquet halls, etc., improve the network communication conditions, and provide a place for tired tourists to rest. It can also meet the leisure needs of travelers in the same city in their leisure time, increase the stay time of tourists, and obtain economic income through the consumption of tourists' leisure facilities.

\section{Industry management and investment mechanism}

As an economic industry, museum tourism needs a lot of investment. As a non-profit public welfare organization, the capital injection of museums in China is almost all from government grants and part of social investment. Such a financing method has a single channel, many restrictions and a small amount of funds. Therefore, it is necessary to seek multi-party capital input from the state, local authorities, departments, collectives and individuals. The opium war museum can introduce different industries in the tourism industry chain and encourage private investment. At the same time, carry out cross-regional 
economic cooperation with other museums to stabilize funds.

\section{Government supportive policies}

The government should coordinate relevant departments to give preferential policies to the opium war museum tourism project. Increase investment in infrastructure construction, such as road maintenance outside the scenic spot, to create a safe and healthy surrounding environment for the opium war museum. Set up small vendors selling areas, conduct unified management, do a good job in food safety and commodity quality inspection, and guide the community to participate correctly.

\section{REFERENCES}

1. Song xiangguang. On the development of museums under the condition of socialist market economy. Museum of China. 2003; (01), 3-8.
2. Meng le. On the development of museum tourism in taiyuan. Journal of taiyuan city polytechnic. 2013; (09), 17-18.

3. Qu qingling. Museums and cities growing together -- on the urgency and necessity of building new museums in Dongguan. Heritage and conservation research. 2019; 4(02), 115-118.

4. $\mathrm{Xu}$ mingze. Since the media platform survey research influence on travel behavior; 2017.(Doctoral dissertation).

5. Shen li-sheng and zhu yunfa. Quantitative research on the relationship between human resource development and economic growth. Quantitative economy, technical and economic research.1997; (12).

6. Yu shaobai. On the development and management of museum souvenirs. China museum. 2000 ;(4), 20-24. 